\title{
Critical Discourse Analysis In Indonesia Lawyers Club (Ilc) "Rkuhp Controversy" On Tv One
}

\author{
L.M Ady Marlan Wardoyo Hasim ${ }^{1}$, Lia Maulia Indrayani ${ }^{2}$, Ypsi Soeria Soemantri ${ }^{3}$ \\ ${ }^{1.2 .3}$ Universitas Padjadjaran \\ e-mail: ady19001@mail.unpad.ac.id, lia.maulia@unpad.ac.id ${ }^{2}$,ypsi.soeria@unpad.ac.id ${ }^{3}$

\begin{tabular}{ccc}
\hline Diterima & Direvisi & Disetujui \\
$10-08-2020$ & $30-08-2020$ & $20-09-2020$ \\
\hline
\end{tabular}

\begin{abstract}
On 25 September 2019, Indonesia Lawyers Club (ILC) have made themes Rancangan Kitab Undang Undang Hukum Pidana controversy or RKUHP controversy. ILC discusses several chapters that invite the pros and cons in the interpersonal community of the article concerning the insult to the President and Vice President, article on the possession of supernatural powers to commit a criminal offense, article on poultry breeding, article on demonstrating contraceptives, articles on abortion, and other. In the critical paradigm, the use of language in the media is intentional and has a specific purpose. Seeing this, researchers are interested in seeing the discourse built in the talk show. The researchers used a critical discourse analysis technique model (Teun van Dijk) and found that ILC built a discourse that article RKUHP serves the interests of the Government. The RKUHP intervenes in the privacy of the community, and RKUHP discriminates against certain groups. This discourse also shows the definition and positioning of the ILC position on the participants of the production discourse. ILC placed Karni Iliyas as the dominant moderator so that his reality could be accepted by the public as truth. using the technique of text analysis, social cognition, and context, researchers found a discourse built by ILC confirming the view that the RKUHP invites pros and cons in society.
\end{abstract}

Key Word: critical discourse analysis, RKUHP, talk Show, ILC, TV One

\begin{abstract}
Abstrak - Pada 25 September 2019, Indonesia Lawyers Club (ILC) membuat tema Rancangan Kitab UndangUndang Hukum Pidana kontroversi atau kontroversi RKUHP. ILC membahas beberapa pasal yang mengundang pro dan kontra di masyarakat interpersonal pasal tentang penghinaan terhadap Presiden dan Wakil Presiden, pasal tentang kepemilikan kekuatan supranatural untuk melakukan tindak pidana, pasal tentang pebiaran unggas, pasal tentang menunjukkan kontrasepsi, pasal tentang aborsi, dan lainnya. Dalam paradigma kritis, penggunaan bahasa di media disengaja dan memiliki tujuan tertentu. Melihat hal ini, para peneliti tertarik untuk melihat wacana yang dibangun dalam talk show. Para peneliti menggunakan model teknik analisis wacana kritis (Teun van Dijk) dan menemukan bahwa ILC membangun wacana bahwa pasal RKUHP melayani kepentingan Pemerintah. RKUHP mengintervensi privasi masyarakat, dan RKUHP mendiskriminasi kelompok tertentu. Wacana ini juga menunjukkan definisi dan posisii dari ILC pada peserta wacana produksi. ILC menempatkan Karni Iliyas sebagai moderator yang cukup dominan sehingga kenyataannya dapat diterima oleh publik sebagai kebenaran. dengan menggunakan teknik analisis teks, kognisi sosial, dan konteks, para peneliti menemukan wacana yang dibangun oleh ILC yang menegaskan pandangan bahwa RKUHP mengundang pro dan kontra di masyarakat.
\end{abstract}

Kata Kunci: analisis wacana kritis, RKUHP, talk Show, ILC, TV One

\section{INTRODUCTION}

Indonesia Lawyers Club program is abbreviated to ILC edition 25 September 2019, with the theme of RKUHP controversy. This impression triggered the appearance of the draft Book of criminal law which many of the chapters reaping controversy such as the abortion clause until black magic (santet) which in the end RKUHP delayed its endorsement due to reaping controversy in the public domain.
Rancangan Kitab Undang Undang Hukum Pidana or the RKUHP is a lot of controversy in news in some online media. The RKUHP has been created to regulate criminal acts or anything that is considered an evil deed and to regulate the weight of the punishment. However, there are some points in the RKUHP that are judged to be unclear and thus detrimental to some community communities one of which is women. Reported from various national media, there have been many women organizations that appealed objections will be denied this RKUHP, one of them is the legal expert from Masyarakat 
Pemantau Peradilan Indonesia (MaPPI FH UI) Professor Sulistyowati Irianto for example, criticizes the hard article 285 RKUHP, "Whoever by force or threat of violence forces a woman who is not his wife to be clothed with her, punished, for rape, in prison forever twelve years." This section is judged to still have a narrow meaning. Rape is still considered to be a couple who are not husband and wife, but in many cases, there is some rape that also occurs in the married couple. In addition, rape is also interpreted only for women but also for men who have raped. The wrong mischief of rape will only create a legal loophole that could benefit the perpetrator.

In addition to drafting chapters on rape, the RKUHP is also highlighted for expanding several chapters from online search results on tempo.co and finds variations of news at the same time. The news about the RKUHP peak received attention when in September 2019 legislation board of representatives of the Indonesian people have begun the discussion of the draft book of criminal law which partially raises controversy such as the article of insult President and vice president, abortion until article black magic. Through an online archive search, only ILC gives special attention to this topic due to the many demos of some students in Indonesia. The talk show program in other news TV stations, the Mata Najwa in Trans TV does not raise the phenomenon of RKUHP. The ILC gives attention to indicates that there is a discourse that wants to be built through the news about this RKUHP.

The notion of discourse has three central things: text, context, and discourse (Eriyanto, 2012, p. 9). Study discourse here enters the context because the context affects the production of discourse. In this study, discourse in the ILC "RKUHP controversy" should be seen from the context, such as the political situation especially the dynamics after the election of the President and Vice president.

Some research on media built discourse has been done before. The first is (Mora, 2009), Orientalist Discourse in Media Texts" by Necla Mora in 2009, and also by (De Wet, 2001), A Media Discourse Analysis of Racism in South African School", The two studies are conducted on the coverage of printed media.

Furthermore, different from the above four studies, this study saw discourse built in television media, particularly in the talk show program. The study of discourse in the previous talk show program was "Critical Discourse Analysis of Political TV Talks Shows of Pakistani Media" by Hafiz Ahmad Bilal in 2012. The study used a critical discourse analysis of the Teun van Dijk model but did not carry out dimensions of social cognition analysis. In research on the discourse built in the ILC program "RKUHP controversy," the researcher use the threedimensional Teun van Dijk analysis of the text structure, social cognition, and social analysis, from the reasons that have been expressed above the researchers interested in conducting research on how the discourse built in the Indonesia lawyers Club program RKUHP controversy " on TV One.

On a critical level, according to Foucault discourse is not merely a series of words or propositions in the text. Discourse is something that produces another. Discourse forms a set of certain construct that forms reality. That is, our perception of an object is formed and constrained by the (dominant) view that defines something that this one is true and the other is not. Discourse limits our view of an object. The object may not change, but the rule of discourse is what makes the object change. In mass communication through television, audiences were not controlled by physical exertions, but through discourse on television shows (Eriyanto, 2012, p. 74-75).

Althusser (Eriyanto, 2012, p. 19) describes discourse as a practice whereby a person is positioned in a particular position in a social relationship. Discourse plays a role in defining individuals and positioning someone in a certain position. Certain discourse forms the subject in certain positions in a series of relationships with the social powers that exist in society.

In the CDA, discourse is not understood as a language study as in traditional linguistics but is also associated with the context, in the sense of the language used for certain purposes and practices, including the practice of power. (McGregor 2018), in his writings says "Our words never neutral". CDA investigates how through the language of the existing social group to fight each other and propose its reality.

\section{RESEARCH METHODOLOGY}


The method used in this study is Critical Discourse Analysis/CDA developed by Teun A. Van Dijk, which is often referred to as "social cognition". According to Van Dijk, research on discourse is not enough on the text, but also to be seen in its production practices. Eriyanto (2012, p. 225) described the following model of the van Dijk analysis:

Tabel 1. pictures of model Van Dijk analysis

\begin{tabular}{|l|}
\hline a. Teks \\
\hline b. Social Cognition \\
\hline c. Social Analysis \\
\hline
\end{tabular}

Source: Eriyanto, 2012, p. 225

The models developed by Van Dijk not only look at the microstructure (The text) and the macrostructure (Context) but also the mesostructure that links the text and context, namely social cognition. The text dimension looks at how the text structure and the discourse strategy used to assert a particular theme. Then the dimension of social cognition has two meanings. First, social cognition shows how the text process produced journalists/media themselves. Secondly, social cognition illustrates the values of society spreading and absorbed by journalists, and is finally used to create the news text. The last dimension is social context. This dimension learns the building discourse that develops in the community about a particular problem (Eriyanto, 2012, p. 222-224).

To analyze discourse, Van Dijk divides the analytical techniques into three-dimensional analysis such as text structure, social cognition, and social Analysis (Eriyanto, 2012, p. 229-274).

\section{Text Structure}

a. Topics

New news topics can be concluded after reading, listening or watching the news. The important notion of Van Dijk, discourse is generally formed in general rules. The text is not only defined but a coherent general view, i.e. passages in the text pointing at a single point of common idea, and those parts mutually support one another to describe the general topic.

\section{b. Schematic}

According to Van Dijk, the significance of the schematic is the reporter's strategy to support the specific theory that wants to be conveyed by arranging parts in a particular order. The schematic gives the pressure of which part takes precedence and which part can later as the strategy hides the important information. Text or discourse generally has a scheme or plot from the introduction to the end. The plot shows how the parts of the text are organized and sorted to form a unity of meaning.

\section{c. Semantics}

The semantic or meaning to be emphasized in the text can be seen from several things such as background, detail, intent, and presuppositions. The background, details, and intent relate to which information is emphasized and get more portions. Meanwhile, the pre-supposition element is a statement used to support the meaning of a text.

\section{d. Syntactic}

The syntactic relates to how the sentence is selected. Syntactic can be seen from coherence, denial, sentence form, and pronoun.

\section{e. Stylistics}

The syntactic relates to how the sentence is selected. Syntactic can be seen from coherence, denial, sentence form, and pronoun.

\section{f. Rhetorical}

The rhetorical relates to how and in what way emphasis is made. Rhetorical can be seen from the use of graphics, metaphors as well as expressions. Graphics see the use of graphs, images, or tables to support the significance of a message. Graphic elements provide cognitive effects, in the sense that they control attention and interest intensively and demonstrate that information is important and should be observed.

\section{Social cognition}

The social cognition sees how a text is produced. Social cognition relates to the mental consciousness of journalists who form the text. Van Dijk departs from the idea that the text itself has no meaning, but is given by the mental consciousness process of the language user. Journalists do not are seen as neutral individuals, but individuals who have an assortment of values, experiences, and ideological influences gained from their lives. Van Dijk mentions that events are understood and understood according to the scheme. The scheme conceptualized as the mental structure in which it is covered how we perceive human beings, social roles, and events. There are several kinds of schemes/models that can be described as the following: 


\section{a. Person scheme}

This scheme illustrates how someone is spreading and looking at others. For example, how Islamic journalists look at and understand Christians will influence the text of the news he writes.

\section{b. Self scheme}

This scheme relates to how self-perceived, understood and described by someone.

\section{c. Role schemes}

This scheme relates to how one looks and describes the role and position that a person has occupied in the community.

\section{d. Event scheme}

This scheme is probably the most widely used because almost every day we always see and hear events. And every event is always interpreted and specified in certain schemes. Generally, this scheme of events is the most widely used by journalists.

The Model is very related to social representation, namely how the views, beliefs, and prejudice that flourish in society. Journalists live among the beliefs and views of society. However, how the belief affects journalists will be influenced by the journalist's experience, memory, and interpretation.

For Van Dijk, social cognition is primarily related to the news production process. The production of news is mostly and especially happening in the cognition of a journalist. Therefore the main question posed by Van Dijk is how journalists hear and read events, how they are understood, interpreted, and presented in mind. How the event was focused, selected, and summed up in the overall the news production process how the information that has been owned and held by the reporter is used in producing the news.

\section{Social analysis}

The important point of this analysis is to demonstrate how the meaning is being shared, social power is produced through the practice of discursus and legitimacy. According to Van Dijk, in the analysis of this society, there are two important points: power and access.

a. Practice of power
Van Dijk defines power as the ownership of a group (or its members) controlling other groups. This power is generally based on possession or resources of value such as money, status, and knowledge. Power is not only gained through physical control, but also through persuasive sleep by way of affecting mental conditions such as belief, attitude, and knowledge. The analysis of discourse gives attention to domination. Domination is reproduced by granting special access to one group than other groups. He also paid attention to the production process through legitimacy through the form of mind control.

\section{b. Access affects discourse}

The analysis of discourse gives attention to access, how to access each group in the community. The elite group has greater access compared to the group. Therefore, the more powerful have a greater chance of having access to the media, and the greater chance of influencing audience awareness through control over the topic and content of discourse.

\section{FINDINGS AND RESULTS}

In a schematic, ILC data "RKUHP controversy" may be presented in the table bellow:

Table 2. Schematic data findings

\begin{tabular}{|c|l|l|}
\hline Time & Segment & \multicolumn{1}{c|}{ Description } \\
\hline 00.58 & $\begin{array}{c}\text { Opening of } \\
\text { ILC }\end{array}$ & $\begin{array}{l}\text { ILC gives a statement } \\
\text { that the article appears } \\
\text { on the RKUHP that } \\
\text { invites the pros and } \\
\text { cons. }\end{array}$ \\
\hline $01.41-$ & $\begin{array}{l}\text { Article 218 } \\
\text { related to the } \\
\text { humiliation of } \\
\text { the President } \\
\text { and Vice } \\
\text { president in } \\
\text { particular in } \\
\text { paragraph one. } \\
\text { Sound Article } \\
\text { person who publicly } \\
\text { attacks the honor or } \\
\text { dignity of the President } \\
\text { or the vice president } \\
\text { and can be sentenced } \\
\text { and singed to make a } \\
\text { government that is } \\
\text { queued by criticism of } \\
\text { the community. } \\
\text { one }\end{array}$ \\
\hline $\begin{array}{l}\text { Article 252 on } \\
\text { possession of } \\
\text { supernatural } \\
\text { powers to }\end{array}$ & $\begin{array}{l}\text { ILC makes this article } \\
\text { a rule that is not } \\
\text { acceptable to the logic } \\
\text { of society. ILC makes }\end{array}$ \\
\hline
\end{tabular}




\begin{tabular}{|c|l|l|}
\hline & $\begin{array}{l}\text { commit } \\
\text { criminal acts. }\end{array}$ & $\begin{array}{l}\text { this article a rule that } \\
\text { does not enrich society. }\end{array}$ \\
\hline $\begin{array}{c}\text { 33.25- } \\
\text { Article 278 on } \\
\text { poultry } \\
\text { breeding }\end{array}$ & $\begin{array}{l}\text { ILC makes this article } \\
\text { an impartial rule on } \\
\text { society and tends to } \\
\text { harm some parties } \\
\text { especially farmers. }\end{array}$ \\
\hline $\begin{array}{l}\text { 49.00- } \\
64.12\end{array}$ & $\begin{array}{l}\text { Article 414 on } \\
\text { demonstrating } \\
\text { contraceptives }\end{array}$ & $\begin{array}{l}\text { ILC made this article } \\
\text { an exemplary example. }\end{array}$ \\
\hline $64.13-$ & Karni Iliyas \\
statement & $\begin{array}{l}\text { ILC provides the } \\
\text { conclusion Karni Iliyas } \\
\text { to recall that the } \\
\text { current many articles } \\
\text { of the RKUHP that are } \\
\text { not important funds do } \\
\text { not bring welfare to the } \\
\text { community. }\end{array}$ \\
\hline
\end{tabular}

The data findings show that thematic episodes of the RKUHP controversy criticized the existence of the adverse chapters for not exercising the function properly. Article 218 is related to the humiliation of the president and Vice president, especially in subsection (1). The sound of article 218 paragraph (1), article 252 on the ownership of the supernatural powers to commit a criminal act, section 278 on poultry breeding, article 414 on the performance of contraceptives, article 470 on abortion, article 604 about criminal acts of corruption and others. It means that in general, the RKUHP is formed to serve the public interest in general.

There are several discourses built in the ILC RKUHP controversy:

\section{Article related to the humiliation of the President and Vice President}

Article 218 is related to the humiliation of the president and Vice president, especially in subsection one. The sound of article 218 paragraph one is:

"Every person who publicly strikes the honor or dignity and self-esteem of the President or Vice President is sentenced to imprisonment for a maximum of 3 (three) years 6 (six) months or a penalty of the most category IV"'(SUYUTI, 2019)

The issue of this article only serves the interests of the Government has been raised since the beginning, through the opening of ILC: (one) "article on the contempt of the President and Vice president indirectly offers a fast road to achieving the public's observance".

Karni Ilyas used a combination of metaphorical "fast roads" so as to provide presuppositions against the chapter as a legal product of the ruling government in order to fulfill the interests of the Government without seeing the consequences of the implementation of the article for society throughout Indonesia.

\section{Article criminal problem of abortion contained in article 470 paragraph (one) of RKUHP}

Data findings indicate a sub-episode of the criminal clause against abortion. "Any woman who has a loss or death of her womb or has someone else to kill or turn off the content is sentenced to prison for the longest 5 years".

In an interview with Yasonna, Karni Iliyas let Yasonna provide detailed information on the article that it is stated that the criminal threat of abortion is lower and does not apply to rape victims. After Yasonna was completed, Karni Iliyas started the establishment of the RKUHP discourse to interfere with the private affair as in the following conversations:

KI: So indeed do you see this more to the private affairs?

YS: Yes..

KI: means that private affairs do not necessarily be regulated in the public domain.

YS:Aaa... What.. Aaa. The fixed rule should be adjusted to the effect given to the other community

KI: Since then you say it's their business, this means it is indeed something that does not need to be arranged, especially to the criminal.

In the first sentence, Karni Iliyas issued a question that is also presuppositions that according to Yasonna abortion or abort content is a private affair, with the description/coherence of human affairs with their God, are private affairs. This is then emphasized in the third sentence with the coherency because of the consequence that the affair of abortion does not need to be arranged in the article because it is a private affair. Yasonna then gave an explanation that the rules remained in adjusting with the effects given. However, in the last 
sentence, Karni Iliyas again use the coherency cause of consequences. The cause is abortion is a human private affair with God, as a person so there is no need to be organized in the public domain. In the cause proposition, Karni Iliyas added the explanatory coherence "because you said" to assert that Yasonna himself admitted that the affair of abortion is private affairs.

\section{Article 278 on poultry in the RKUHP}

"Everyone who let the poultry that is treated in the garden or land that has been sprinkled by the seed or other crops are sentenced to the fines of the most category II" in minutes 33.25-48.20 Karni Iliyas raised this discourse by feeding Yasonna to provide details by asking "What about the poultry article, do you think that the article does not harm the other party?"

Yasonna then gave details that the fine of category II, as stated in article 79 amounting to Rp10.000.000. In the old criminal code, the prohibition of this problem is also governed by article 548. The findings of the data shown in the same text Yasonna gave the coherency differentiator between the fines to be paid by the people who are still connected to the old rules that the article was discussed earlier.

\section{CONCLUSION}

The researchers used the critical discourse analysis technique of Van Dijk model and found that ILC built three discourse such as the article related to the humiliation of the President and Vice President, the article criminal problem of abortion contained in article 470 paragraph one of RKUHP, the article 278 on poultry in the RKUHP.
The researchers found that the production of a talk show that ILC did not only roll out the discourse but at the same time to answer the public's needs, thus culminated to match the interests of ILC - TV one. Other academics can conduct analysis research on other critical discourse, so that can be developed a more efficient model of critical discourse analysis for text-based audiovisuals. Subsequent studies can see critical discourse from other perspectives e.g. specifically looking at the latest political issues on TV One or eloquence/speaking ability of all the speakers at ILC.

The media practitioners must be critical in the production of text, seeing the produced text containing discourse that can affect the community. The production of media texts must be done with jellies in order to be social transformation means to support clean and honest democracy practices. The discourse formed should not only critique but also provide solutions for the media to be a driving agent and change in a positive direction.

\section{REFERENCES}

Eriyanto.(2012). Analisis wacana: pengantar analisis teks media. Yogyakarta: LKiS

De Wet, C. (2001). A media discourse analysis of racism in South African schools. International Education Journal, 2(5), 98-112.

McGregor, S.L. (2018). Critical discourse analysis: A primer.

Mora, N. (2009). Orientalist Discourse in Media Texts. International Journal of Human Sciences, 6(2), 419-428.

SUYUTI, H. (2019). Rancangan Kitab Undang Undang Hukum Pidana. September, 5-10. 